\title{
股関節全置換術後の大腿骨々幹部骨折
}

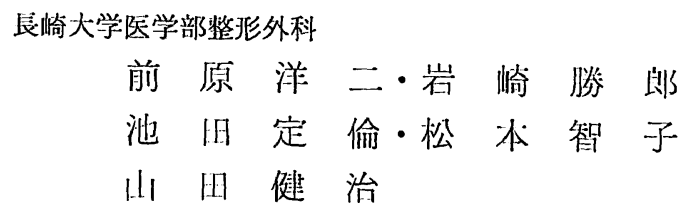

\section{Fractures of the Femoral Shaft after Total Hip Replacement and Their Management}

by

\author{
Youzi Maehara, Katurou Iwasaki, Sadanori Ikeda \\ Tomoko Matsumoto and Kenji Yamada \\ Department of Orthopaedic Surgery Nagasaki \\ University School of Medicine
}

\begin{abstract}
Five femoral shaft fractures occurred in 221 hips after Charnley total hip replacement. Four of five fractures were fixed with the K-U plate; of three fractures bone grafts were added. It was possible to insert screws into the bone in the presence of cement and stem, and to get rigid fixation of the fracture site. Bone union was completely achieved in all of the cases. Altyough a lot of methods have been reported in their management, we considered that fixation with the plate is more useful than other methods.
\end{abstract}

はじめに

Charnley 型股関節全置換術（以後 T. H. R）後 の合併症のうち大腿骨々幹部骨折はそれ程多く発生す るものではない，その治療法に関しても紫藤らは鋼線 笔引による保存的療法で骨喻合を得たと述べ, 㐿藤, 明石, Scott らはlong stem による入㣗替えが有用で あると言っており，また竹多は 1 例ではあるが plate 固定を用いた経験を報告しているがまだ確立したもの はない.

我々はての骨折に対して K-U plate を用いて皘極 的に骨接合術を行うことにより，比較的満足すべき絬 果を得たので報告する。

\section{症例}

昭和 46 年 1 月より昭和 59 年 6 月までに長崎大学整 形外科にて行った T. H. R. 221 関節中 4 例（5骨 折）に本骨折を生じた，症例の内訳けは男 1 例，女 3 例. 年令は 43 才 58 才 (平均 50.2 才)。原疾患は男
表 1 症例の内䛌けおよび治疗法

\begin{tabular}{|c|c|c|c|c|c|}
\hline 症例 & 性 & 年令 & 原 疾 患 & 骨折の原因 & 治 痛 \\
\hline 1 & 男 & 50 & $\begin{array}{l}\text { 左大瑯骨 } \\
\text { 骨頭㯃死 }\end{array}$ & $\left|\begin{array}{llll}1 & \pi & 5 & 0 \\
\text { 立 } & 5 & 上 & b\end{array}\right|$ & $\mathrm{K}-\mathrm{U}$ plate \\
\hline 2 & 女 & 43 & 右変股症 & 忶＼cjkstart倒 & $\begin{array}{l}\text { K-U plate } \\
\text { 十骨移植 }\end{array}$ \\
\hline 3 & 女 & 58 & " & 階段昇降特 & $\begin{array}{c}\text { K-U plate } \\
\text { 十骨移植 }\end{array}$ \\
\hline 4 & 女 & 58 & 閜変股症 & 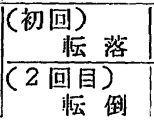 & $\begin{array}{c}\text { Screw 固定 } \\
\text { +Cast brace } \\
\text { K-U plate } \\
\text { +骨移椎 }\end{array}$ \\
\hline
\end{tabular}

性例が大腿骨々頭壊死であり女性例は全て変股症であ った．骨折の原因は転倒 2 例，イスより立ち上り洔が 1 例, 縁倒より枟落 1 例, 階段显降訓練中 1 例であっ た（表 1)。また THR より骨折までの期間は短 48 日から最長 5 年 8 力月．骨折より骨接合術までは全例 に直達率引を行いその期間は 10 日から 40 日の間であ った.

骨折部位は stem や cement の先端部に生じたも のが 4 骨折で， 1 骨折はこの部位よりやや中枢部であ 
り，骨折型は斜骨折 3 例，横骨折 1 例，ラセン管折 1 例であった。

于術は K-U plate による周定 1 例, K-U plate 固 定士骨移枯 3 例で，残りの 1 例は 2 回骨折例の初回治 療例であり screw 周定後, cast-brace 老装着した。

全荷坐少行は 4 力月上り 6 力月（平均 4.7 力月）で

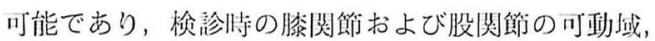
日整会股闺筑判定基準は表 2 の如くである。症例 4 の 膝|関䬣の属曲，伸展陵㕩は初回骨折治療後に残ったも のである．滕関節，股関節の可動域は良好な結果が得 られた，又骨炴合は全例に得られたが，ADL 上で 2 回骨折例は屋外活動が困難であるが他の 3 例は以前の 仕:事（信作業，漁業，家事）に就業している。

次に症例を供覽する。

症例 1.M. M. 男性 左大腿骨々頭壊死

50 才 合作症：煻疗病（インシュリン治療中）THR 前の日整会股関節判定基準点数（以後判 定基準之す る） 29 点. 術中には特に問題はなかった，T.H. R より約 11 力月後イスより急に立ち上万うとして骨折 を生じた，骨折は cement の尖端にあり斜骨折で旡 位していた，治療は K-U plate 固定による骨接合術 をおこなった，骨海合は良奵であり見在你業に従事し ている．検晾恃日整会判定基準 73 点（図 1 ）.

症例 2. S. M. 女性 石変股症 43 才, T. H. R 前の判定基準は 49 点. 術中には問題はなかったが， 術後約 3 年 4 力月後愢回䣦中の荷台上り枟倒して骨折 を生じた，咼折は stem 尖端を通る横骨折で枟位して
表 2 K-U plate 周定後の結果

\begin{tabular}{|c|c|c|c|c|c|c|}
\hline \multirow{2}{*}{ 症例 } & \multirow{2}{*}{$\begin{array}{l}\text { 全荷㭕 } \\
\text { 歩 行 }\end{array}$} & \multicolumn{2}{|c|}{ 滕 阙 领 } & \multicolumn{2}{|c|}{ 股 阙 節 } & \multirow{2}{*}{$\begin{array}{l}\text { 日 整 会 } \\
\text { 股 閃 } \\
\text { 判定基準 }\end{array}$} \\
\hline & & 屈 曲 & 伸展 & 属曲 & 外転 & \\
\hline 1 & 4 力月 & $140^{\circ}$ & $0^{\circ}$ & $70^{\circ}$ & $15^{\circ}$ & 73点 \\
\hline 2 & $5 "$ & $140^{\circ}$ & $0^{\circ}$ & $90^{\circ}$ & $25^{\circ}$ & $80 "$ \\
\hline 3 & $4 \prime$ & $140^{\circ}$ & $0^{\circ}$ & $80^{\circ}$ & 20 & 53 " \\
\hline 4 & 611 & $100^{\circ}$ & $10^{\circ}$ & $70^{\circ}$ & $15^{\circ}$ & $35 "$ \\
\hline
\end{tabular}

いた，治療は K-U plate 固定をおこない骨折部周围 に骨移植を追加した. 治療後 1 年 9 カ月の検部恃には 要作業は十分に可能とのことであった，日整会判定 80 点 (図 2 ).

症例 3 . F. S. 女性右変股症 48 才. T.H.R 前判 定基蕉 43 点. 術後X線で stem 尖端の外側に少昷の cement 流出像を悡めた. しかし stem は外反位に固 定され, cementing あ良好であったのでそのまま機 能訓練を開始したが，48 日後階段舁降亷練中に，骨折 を生じた，骨折は stem 尖端を通る斜骨折で転位があ った. 手術所見では stem 尖端部で大腿骨の前外倒部 飞骨欠損があり，てれが骨折線と連続していた．治療 は骨欠損部求よび骨折部周国に腸骨よりの骨移植をお こない K-U plate 固定をおこなった. Plate 固定後 2 年 5 力月後の検䛦壯は, 骨漟合は得られており家事 一般はできるとのととであった。 判定基準 53 点（図 $3)$.

症例 4.5 . $\mathrm{T}$ 女性 雨变股症. 58 才. 2 回骨折症 例であり T. H. R 前の判定基準は 21 点. 右 T.H. R

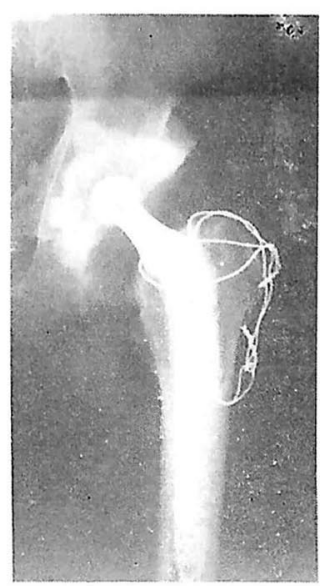

T.H.R 上り 6 力月後

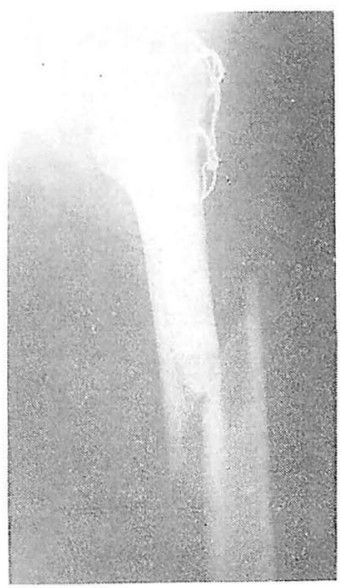

T.H.R より 11 力月後 睯折した。

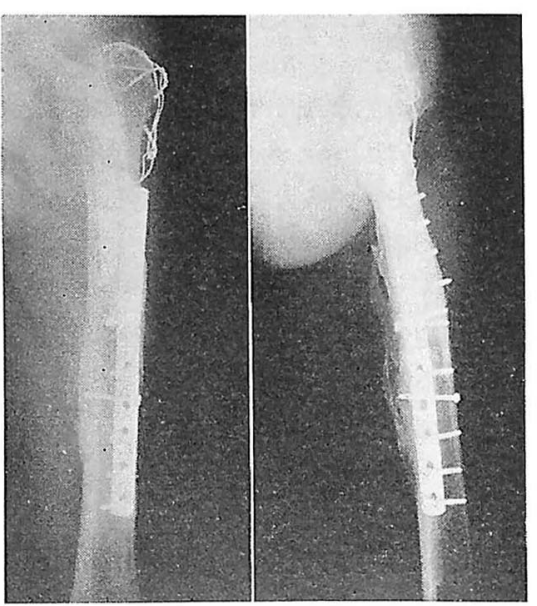

K-U plate 固定後 2 年 8 力月

図 1 症例 150 f 男性 


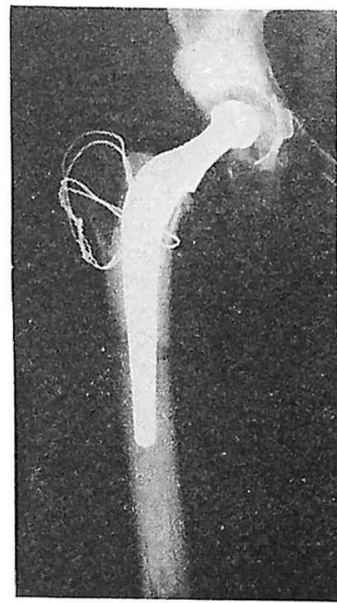

T.H R. 直後

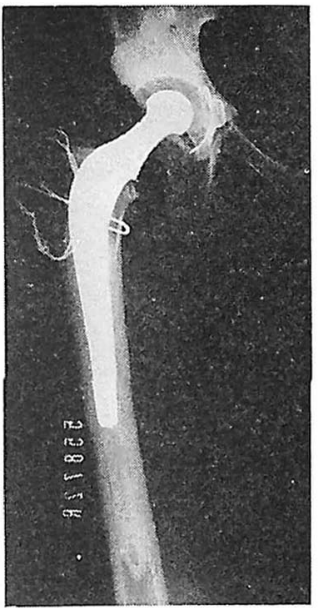

T.H.R 上り 2 週目

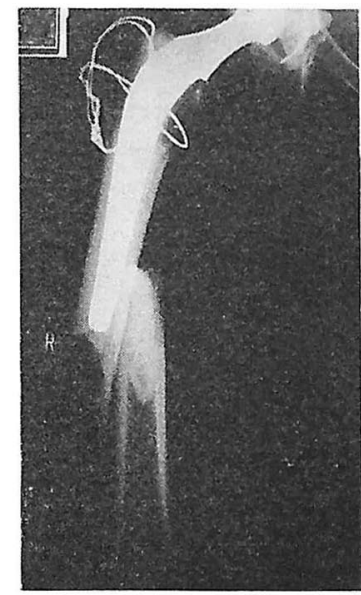

T.H R上.り 3 年 4 力月後に 骨折.セメント骨折むある.

図 2 症例 243 才

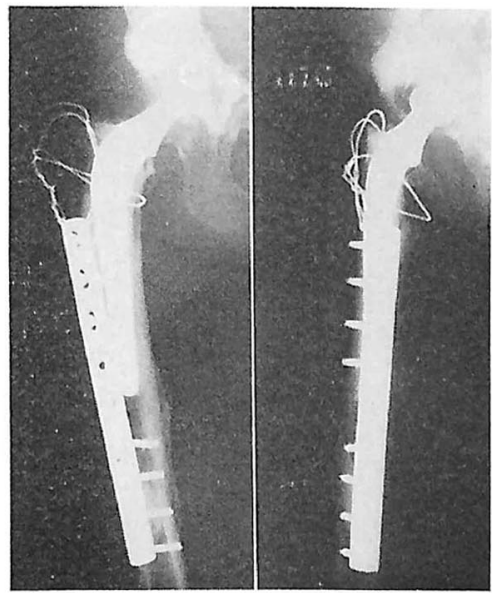

K-U plate 固定後 1 年 9 力月後.

女性

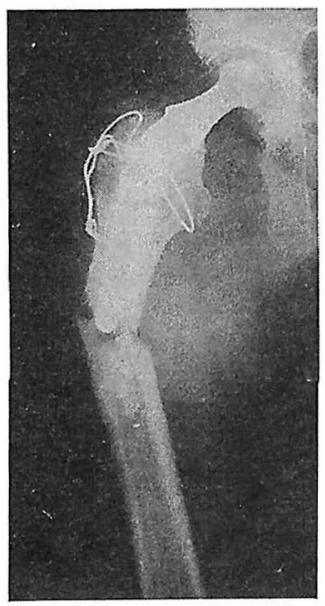

T.H.R より48日後に 骨折

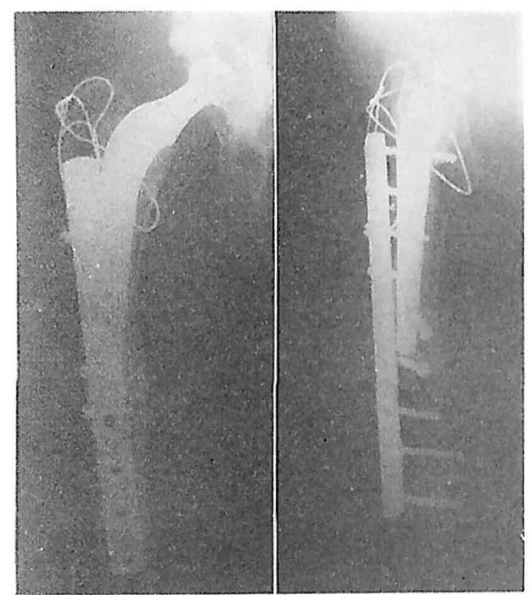

$\mathrm{K}-\mathrm{U}$ plate 固定後 2 年 5 力月後

図 3 症例 3 58才 女性

直後にX 線像で stem 尖端が大腿骨外側に突出してい るととがわかり約 1 力月後再手術を施行した，初回骨 折は術後約 1 年目に縁側より横転して骨折を生じその 骨折はセメント尖端に通る長いラセン骨折であった。 治療はまず screw 3 本にて骨接合術をおてなったが 経過中に骨折部の再転位が出現したため, 牽引の後 cast-brace 法を追加し骨演合に成功した（図 4).2 回目の骨折は初回骨折時上り約 4 年 7 力月後に歩行中 石につまずいて転倒して生じた，骨折は stem 尖端
を通る斜骨折であり，術中所見では stem が舠拈 より $3 \sim 4 \mathrm{~cm}$ 程度突出していた，治療は邀位骨片の cement を一部除去して整復後骨移植を加え, K-U plateを用いて骨接合をおこなった，plate 固定後 10 力月目のX線像では骬燋合は完成していた。晛在 は家事がやっとであり常に 1 本杖を使用しており判定 基準は 35 点であった。 


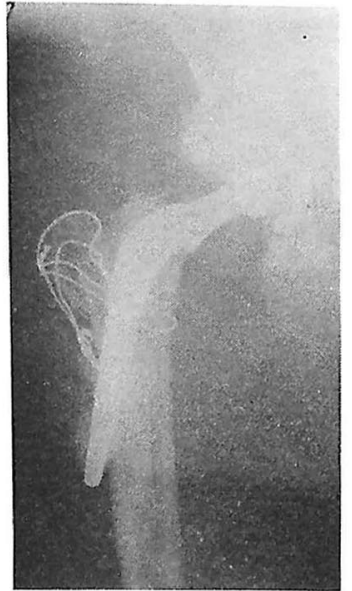

T.H.R 直後. 1 力月後 Stem の再拆入.

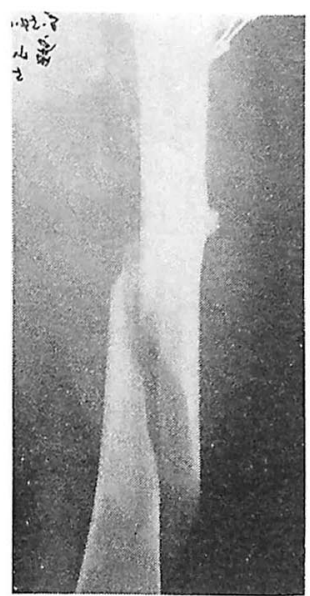

T.H.R より 1 年後に骨折 し長いラセン骨折である。

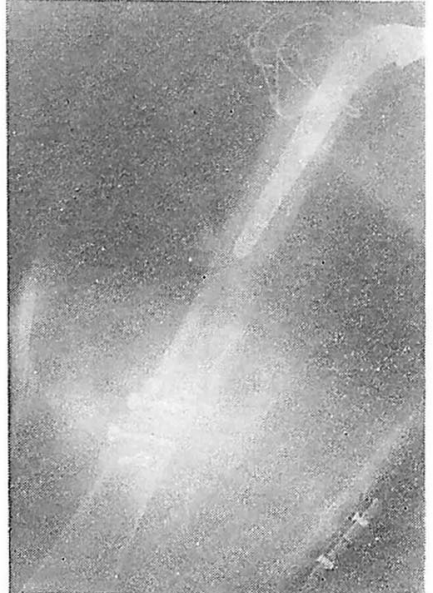

Screw 周定後 Cast brace を装胼。

図 4

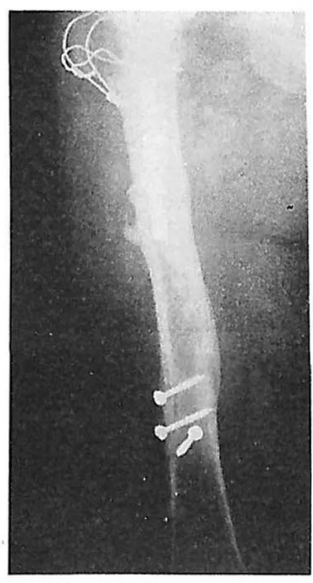

初回骨折治隐猔

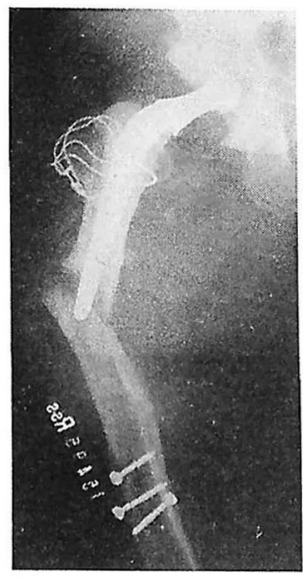

初回骨折上り 4 年 7 力月後飞再骨折

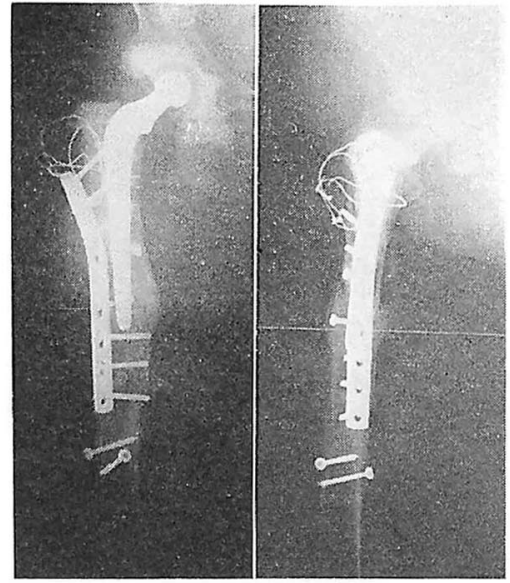

K-U plate 固定後10力月 骨猛合は完成している。

図 5 症例 4 の 2 回目骨折の治瘄経過

考

察

T. H. R 後の大䛧骨々翰部骨折の発生頿度は Scott $0.1 \%$, LeinBach $0.4 \%$ とする報告があり，本邦で は为滕が $1.1 \%$ あっったと述べている。乙れに比較し てむ私々の $1.8 \%$ という発生頻度は高い数值である. ここでは䯚折の原因としては stem の loosning, reaming による骨皮所の非滇化および穿孔，再手術

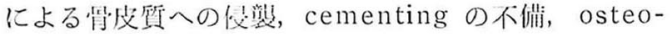
prosis，肥满なよ゙が考えられている。私々の症例中 2
例は術中の reaming の穿孔があり，またこの症例に は肥湍や osteoprosis むありこれらのととも関与し ていると思われるが，いずれにしても慎重な reaming によって骨の強度を失なわせないような術中の配 虑が必要なととはいうまであない. また機能訓練のス ケジュールをおくらせるととや日常生活動作に関して の注意む重耍なととである。

本骨折の治療としては骨折部を越える long stem で入れ管え, cement で固定することが碓笑であると るす報告が多いが，この方法はセメント除去など技術 
的にあ奞かしく，また T. H. R 後の関節を再度開け るととによる感染の伦除性がある，涪引療法は骨折の 程度によっては邀応であるかす知れないが股関節およ び膝関節の運動制限が出現しやすいし，長期臥床も強 いられ特に高令者には適さないと思われる。

plate 固定による治療にあたっては䯣腔内に stem や cement が存在するために適切な部位に plateを 当てることができず固定性も弱いのではないかという 事や, cement の存在が骨煵合にとって不利であるて となどが考えられていた. しかしわれわれは K-wire を利用してそれが stem に当たらず䯣腔を通りぬけ る方向をさがし，その方向に screw を入れるてとに より plate により骨折部を固定することができた.し かむ固定性も比較的良好であり, 術後の外固定は不要 であった，後療法に関しても通常の大腿骨骨幹部骨折 に対して K-U plate 固定をおてなったのと同様にで きた. そのため膌および股関節の可動性む良好であっ

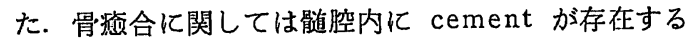
にあかかわらず, 全例に得られた.

以上のととにより T H. R 後の大腿骨々幹部骨折 の治療法として plate 固定による骨接合は有用で あ ると考えた.

$$
\text { ま と め }
$$

1. T. H. R 後の大腿骨々幹部骨折 4 症例 5 骨折 を経驗した. この内 4 骨折に K-U plate 固定をおて ない骨移植を 3 例に追加した.

2. Plate 固定は䯣内に stem や cement が存 在していてあ可能であり, 良好な固定性が得られ，全 例骨瘉合に成功した。

3. T. H. R 後の本骨折の治療において, いろい ろな方法が報告されているが, plate 固定は有用な方 法であると思う.

\section{文献}

1）明石武彦ほか：全人工股関節置換術における一 合併症大腿骨骨折を伴った一症例. 中部整災誌. 15: 616-617, 1972.

2) Alikhan, M. A. et al.: Fractures of the femur during total hip replacement and their management. J. Bone Joint surg., 56-B : 36-41, 1977.
3) Leinbach, I. S. et al.: 700 total hip replacement. Clin. Orth., 95: 174-192, 1973.

4) Mckee, G. K. et al.: The statistic of the McKee-Farrar method of total hip replacement. Clin. Orthop., 95: 26-35, 1973.

5）竹多外志ほ加：人工股阘節罡掺術後の stem 折損並びに大腿骨骨折の再手術例についての倹 討. 整形・災皆外科 27:1175-1181, 1984.

6）斉藤進ほか：股阅節全䠄换術における術中術 後の大腿骨骨折の治痛経験. 中部整災誌，23: 1162-1167, 1980.

7）斎藤 進ほか：Long stem による股闺節全置 换術の経験。中部獘災誌, $24: 348-351,1981$.

8）紫藤微郎ほか：THR における大腿骨 stem の loosening 飞伴う大煺骨骨折の治癌. 人工関節 研究全記録, 12：44-45, 1982.

9) Scott, D. R. et al.: Femoral fractures in conjunction with total hip replacement. J. Bone Joint Surg., 57-A : 494-501, 1975.

10) Scott, D. R. et al.: Avoiding complications with longstem total hip-replacement arthroplasty. J. Bone Joint Surg., 57-A: 722, 1975.

\section{質 問笓児島市立病院 谷口 良康}

私共む 2 例の骨折例を経験しています. 骨折の原因 は loosening による病的骨折で, bone atrophy 著 明で，とてあ骨接合術の適応ではなく，化の方法を採 用しています，骨接合術に成功され，今後の参考にい たしますが，はたして， stem を避けて，スクリウー 刺入可能かと思っています.

解 答長崎大学 岩崎 腅郎

(1) 大腿骨例の loosning を示す, 疼痛や clear zone をみとめた例はなかった.

(2) Screw の㨂入に関しては, 思ったよりむ,うま く対側の皮質をとらえる事ができ固定むよかった.

解 答長崎大学 前原 洋二

(1) 私々の症例では loosning 例はなかった. 又骨 plate は固定性はよい.

(2) 最初私々も一番そのととを心配したが実際やっ てみると, 可能であり張固定性む良好である. 